\title{
UTJECAJ GENOTIPA I GODINE NA UDIO BJELANČEVINA OZIME PŠENICE NA LOKACIJI OSIJEK
}

\author{
G. JUKIĆ ${ }^{1}$, K. ŠUNJIĆ ${ }^{1}$, I. VARNICA ${ }^{1}$, Ivana RUKAVINA ${ }^{1}$, I. DELIĆ ${ }^{2}$ \\ ${ }^{1}$ HAPIH - Centar za sjemenarstvo i rasadničarstvo \\ CAAF - Center for Seed and Seedlings \\ ${ }^{2}$ Ministarstvo poljoprivrede \\ Ministry of Agriculture
}

\section{SAŽETAK}

Tijekom 2018., 2019. i 2020. godine provedena su poljska istraživanja o utjecaju genotipa, godine i njihove interakcije na udio bjelančevina u ozimoj pšenici. U pokus je uvršteno trinaest genotipova ozime pšenice domaće $\mathrm{i}$ strane selekcije koje su zastupljene na domaćem tržištu. Pokus je postavljen u HAPIH - Centru za sjemenarstvo i rasadničarstvo na lokaciji Osijek

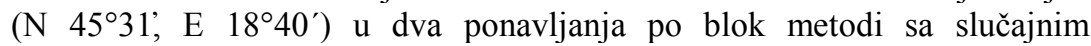
rasporedom (RCBD) uz primjenu standardne agrotehnike za ozimu pšenicu. Cilj rada bio je utvrditi utjecaj genotipa ozime pšenice na udio bjelančevina kako bi genotipove grupirali u klase prema Pravilniku o ugovornim odnosima pri otkupu pšenice. Prema dobivenim rezultatima analize varijance za genotip, godine i interakcije genotip x godina dobivene su statistički visoko opravdane razlike $(\mathrm{P}<0,01)$. Prosječni udio bjelančevina trogodišnjeg istraživanja genotipova kretao se u rasponu od 11,5 do 13,4\%. Dobiveni rezultati ukazuju na mogućnost izbora genotipova s višim bjelančevinama.

Ključne riječi: ozima pšenica, genotip, udio bjelančevina, klase i kakvoće

\section{UVOD}

Pšenica (Triticum Aesttivum L.) je najvažnija zrnata škrobna biljka koja se koristi za ljudsku prehranu i druga je na ljestvici ukupne proizvodnje žitarica odmah iza kukuruza. Najveći proizvođači pšenice u svijetu su Indija (30.230.000 ha), Rusija (27.312.777 ha), države članice EU (26.956.066 ha) i Kina (24.348.396 ha). Proizvodnja ozime pšenice u Hrvatskoj varira, a prema podatcima iz 2018. godine kreće se u zadnjih pet godina od 118.350 do 171.400 ha, te je uz kukuruz najznačajnija kultura u Hrvatskoj (FAOSTAT 2018.). Velike oscilacije u proizvodnji prvenstveno su povezane s velikim oscilacijama u otkupnoj cijeni, koja je uvođenjem Pravilnika o parametrima kvalitete i kvalitativnim klasama pšenice u otkupu pšenice roda 2018. godine i Pravilnika o parametrima kvalitete i kvalitativnim klasama pšenice povezana 
prvenstveno s hektolitarskom masom i udjelom bjelančevina. Prosječni prinos zrna u svijetu iznosi 3,38 t/ha, a prosječni prinos zrna u Hrvatskoj u zadnjih 10 godina kretao se od 4,04 t/ha do 5,80 t/ha (FAOSTAT 2018.). Kovačević i Rastija (2014.) navode kako se najviši prinosi zrna ostvaruju u zemljama Zapadne Europe s prinosom iznad 7 t/ha. Vlastitom proizvodnjom Hrvatska zadovoljava svoje potrebe, ali zbog izvoza sirovine i velikog uvoza gotovih pekarskih proizvoda gube se velika financijska sredstva. Niski prosječni prinosi i udio bjelančevina rezultat su odabira genotipova i smanjenim ulaganjem u proizvodnju što je u korelaciji s niskom otkupnom cijenom.

Značajan utjecaj godine na postizanje dobre kvalitete zrna ozime pšenice naglašavaju $\mathrm{J}$ o 1 a $\mathrm{n} \mathrm{k} \mathrm{a} \mathrm{i} \mathrm{Birkas} \mathrm{(2013.)} \mathrm{koji} \mathrm{navode} \mathrm{kako} \mathrm{su} \mathrm{tlo} \mathrm{i} \mathrm{klima} \mathrm{osnovni}$ čimbenici koji izravno utječu na prinos i kakvoću zrna. Njihovo djelovanje na biljku može biti pojedinačno i zajedničko.

Provedena istraživanja imala su za cilj ispitati razlike između udjela bjelančevina kod pojedinih genotipova na lokaciji Osijek. Rezultati istraživanja pozitivno će doprinijeti rješavanju problematike izbora genotipa s ciljem maksimalnog iskorištenja genetskog potencijala pojedinog genotipa za visoki udio bjelančevina.

\section{MATERIJAL I METODE RADA}

U poljskim pokusima tijekom 2018., 2019. i 2020. godine testirani su domaći i strani genotipovi ozime pšenice koji se nalaze na tržištu. Pokus je postavljen u HAPIH -

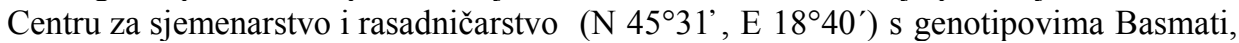
Bc Anica, Bc Lorena, Bc Ljepotica, BcMandica, Bc Opsesija, Kraljica, Maja, Mia, Silvija, Sofru, Tenor i Tika-Taka. Odabrani genotipovi osiguravaju visoku rodnost i kakvoću sjemena. Poljski pokus postavljen je u dva ponavljanja na lokaciji Osijek po blok metodi sa slučajnim rasporedom (RCBD). Tehnologija proizvodnje u godinama istraživanja bila je jednaka, a predusjev je bila soja. Osnovna obrada bila je u jesen zaoravanjem $500 \mathrm{~kg} /$ ha NPK gnojiva 7:20:30, te je izvršena predsjetvena priprema sjetvospremačem. Sjetva je obavljena u optimalnim agrotehničkim rokovima mehaničkom žitnom sijačicom Wintersteigerna dubinu od 3-4 cm. Veličina osnovne parcele iznosila je $10 \mathrm{~m}^{2}(8 \times 1,25 \mathrm{~m})$. Prihrana je obavljena dva puta s ukupno $240 \mathrm{~kg}$ $\mathrm{N} /$ ha KAN. U zaštiti od korova u godinama istraživanja primijenjen je herbicid aktivne tvari florasuram $15 \%+$ aminopiralid $30 \%\left(0,33 \mathrm{lha}^{-1}\right) \mathrm{u}$ fazi prvog koljenca. Preventivno protiv bolesti $u$ fazi cvatnje primijenjen je fungicid aktivne tvari protiokonazol $125 \mathrm{~g} / \mathrm{l}$ x tebukonazol $125 \mathrm{~g} / \mathrm{l}$ (1/ha).Svi prikupljeni podatci analizirani su statistički analizom varijance, a razlike između srednjih vrijednosti tretmana testirane su testom LSD na razini 0,05 i 0,01.

Prema meteorološkim podatcima količina oborina $(\mathrm{mm})$ i temperatura zraka $\left({ }^{\circ} \mathrm{C}\right)$ tijekom godina istraživanja razlikovale su se u odnosu na višegodišnji prosjek (Tablica 1.). 
G. Jukić i sur.: Utjecaj genotipa i godine na udio bjelančevina ozime pšenice na lokaciji Osijek

Tablica 1. Količina oborina i temperatura tijekom vegetacijskog razdoblja 2017/2018-2019/2020

Table 1 Rainfall and temperature during vegetation years 2017/2018-2019/2020

\begin{tabular}{ccccccccc}
\hline $\begin{array}{c}\text { Mjesec } \\
\text { (Mounth) }\end{array}$ & 2018 & $\begin{array}{c}2019 \\
\text { Oborine }(\mathrm{mm}) \\
\text { (Rainfall) }\end{array}$ & 2020 & $\begin{array}{c}\text { Prosjek } \\
\text { (Average) }\end{array}$ & $\begin{array}{c}2018 \\
\text { Temperatura }\left({ }^{\circ} \mathrm{C}\right) \\
\text { (Temperature) }\end{array}$ & $\begin{array}{c}\text { Prosijek } \\
\text { Average })\end{array}$ \\
\hline X & 68,2 & 14,0 & 30,2 & 11,9 & 11,9 & 14,3 & 11,3 & 11,9 \\
XI & 35,4 & 28,8 & 56,4 & 6,4 & 6,4 & 7,4 & 5,8 & 5,9 \\
XII & 45,0 & 34,0 & 44,2 & 3,1 & 3,1 & 1,1 & 1,3 & 1,0 \\
I & 55,0 & 26.0 & 16,2 & 43,8 & 3,8 & 0,1 & $-0,6$ & 0,0 \\
II & 59,2 & 25,8 & 30,4 & 35,7 & 0,4 & 4,3 & 1,3 & 1,5 \\
III & 52,8 & 5,8 & 35,6 & 37,9 & 4,1 & 9,4 & 6,3 & 6,5 \\
IV & 6,4 & 72,6 & 20,4 & 59,6 & 16,3 & 12,5 & 11,6 & 11,6 \\
V & 29,8 & 117,0 & 42,6 & 56,2 & 20,0 & 13,6 & 16,6 & 17,1 \\
VI & 103,2 & 72,4 & 48,0 & 84,8 & 21,1 & 22,3 & 19,8 & 20,4 \\
VII & 115,6 & 43.0 & 47,2 & 68,5 & 21,9 & 22,5 & 21,7 & 21,9 \\
Zbroj (Sum) & 570,6 & 439,4 & 371,2 & 407,9 & 10,9 & 10,7 & 9,51 & 9,78 \\
\hline
\end{tabular}

Tijekom 2018. godine imali smo 162,7 više oborina i 1,12 višu temperaturu zraka od višegodišnjeg prosjeka. U 2019. godini bilo je 31,5 više oborina i 0,92 viša temperatura zraka od višegodišnjeg prosjeka, a u 2020. godini imali smo 26,7 manje oborina i 0,27 manju temperaturu zraka od višegodišnjeg prosjeka. Navedene oscilacije u količini oborina i temperaturi zraka u odnosu na višegodišnji prosjek utjecale su na udio bjelančevina u zrnu.

Žetva je izvršena specijaliziranim kombajnom Wintersteiger zahvat hedera 1,25 m. Udio bjelančevina kod svih uzoraka za sve godine istraživanja analiziran je FOS Infratec 1241 analizatorom u laboratoriju HAPIH - Centra za sjemenarstvo i rasadničarstvo.

\section{REZULTATI I RASPRAVA}

Prema rezultatima istraživanja analize varijance za 2018., 2019., 2020. godinu, godine istraživanja, utvrđen je značajan $(\mathrm{P}<0,01)$ utjecaj genotipa, godine i interakcije genotipa $\mathrm{x}$ godine na istraživano svojstvo (tablica 2.). Razlike između genotipova $u$ godinama istraživanja analizirane su LSD testom.

Najveći udio u varijanci svojstva pripada učinku godine, potom genotipa, a najmanji njihovoj interakciji. Prosječne vrijednosti bjelančevina po godinama istraživanja za istraživane genotipove prikazane su u tablici 3. Genotipove smo svrstavali u klase prema Pravilniku o ugovornim odnosima pri otkupu pšenice. Prosječna vrijednost u 2018. godini je iznosila 12,4\% što se svrstava u II. klasu, u 2019. iznosila je 13,8\% što se svrstava u I. klasu, a u 2020 bila je najniža i iznosila je $11,8 \%$ što se svrstava u III. klasu. Najmanji prosječni udio bjelančevina u godinama istraživanja imao je genotip BC Mandica 11,5\% (III klasa), a najviši BC Anica 13,4\%, BC Lorena 13,4\%, Kraljica 13,3\% i Silvija 13,3\% (II klasa) između kojih nema statistički značajne 
razlike (n.s.) Proučavajući 16 genotipova pšenice za svojstvo udiobjelančevina i hektolitarske mase Jukić i sur. (2018.) utvrdili su statistički značajne razlike $(\mathrm{P}<0,01)$ između genotipova, godina $\mathrm{i}$ interakcije genotip $\mathrm{x}$ godina.

Tablica 2. Rezultati analize varijance

Table 2 Results of variance analysis

\begin{tabular}{lccc}
\hline \multicolumn{1}{c}{ Učinak (Effect) } & MS & LSD $(0.05)$ & LSD $(0.01)$ \\
\hline Repeticija (Repetition) & 0,0690 & & \\
Genotipovi (Genotypes) & $2,5915^{* *}$ & 0,1326 & 0,1776 \\
Godina (Year) & $28,318^{* *}$ & 0,0637 & 0,0853 \\
Genotipovi x godina (Genotypes x Year) & $0,6450^{* *}$ & 0,2296 & 0,3076 \\
Pogreška (Error) & 0,0128 & & \\
Ukupno (Total) & 1,3477 & & \\
\hline
\end{tabular}

Tablica 3. Prosječne vrijednosti bjelančevina po godinama istraživanja

Table 3 Average protein amount by years of testing

\begin{tabular}{|c|c|c|c|c|}
\hline $\begin{array}{l}\text { Genotipovi } \\
\text { (Genotypes) }\end{array}$ & 2018. & 2019. & 2020. & Ukupno (Total) \\
\hline Basmati & 11,9 & 12,8 & 11,3 & 12.0 \\
\hline BC Anica & 12,6 & 14,3 & 13,2 & 13,4 \\
\hline BC Lorena & 13.0 & 14,6 & 12,7 & 13,4 \\
\hline BC Ljepotica & 11,8 & 13,7 & 10,9 & 12,1 \\
\hline BC Mandica & 11,3 & 12,4 & 10,9 & 11,5 \\
\hline BC Opsesija & 11,6 & 13,1 & 12,2 & 12,3 \\
\hline Kraljica & 13,1 & 14,8 & 12,1 & 13,3 \\
\hline Maja & 12,8 & 14,5 & 10,8 & 12,7 \\
\hline Mia & 13,5 & 15,1 & 11,1 & 13,2 \\
\hline Silvija & 13,2 & 13,8 & 13 & 13,3 \\
\hline Sofru & 12.0 & 13,5 & 11,4 & 12,3 \\
\hline Tenor & 11,7 & 12,8 & 11,5 & 12.0 \\
\hline Tika Taka & 12,5 & 14,4 & 12,4 & 13,1 \\
\hline Ukupno (Total) & 12,4 & 13,8 & 11,8 & 12,7 \\
\hline
\end{tabular}

Grupiranjem sorti u klase prema Pravilniku o ugovorenim odnosima pri otkupu pšenice (NN 62/19) u trogodišnjem istraživanju sorte BC Anica, Basmati, BC Lorena, BC Ljepotica, BC Opsesija, Kraljica, Silvija, Sofru, Tenor, Tika Taka, Maja i Mia pripadaju II. klasi, a sorta BC Mandica III klasi. Dobiveni rezultati pokazuju da razlike u udjelu bjelančevina između istraživanih genotipova najvjerojatnije nastale kao posljedica genetske različitosti i klimatskih prilika u istraživanim godinama.

Slične rezultate dobili su Vollmer i Mußhoff (2018.) i Jolanka i Birkas (2013.) koji su zaključili da vremenski uvjeti (oborine i temperature) imaju veliki utjecaj na 
udio bjelančevina u zrnu. Horvat i sur. (2012.) utvrdili su da parametri kvalitete ovise o genotipu, lokaciji, godini i njihovim međusobnim interakcijama. Isti autori analizirajući 10 sorti pšenice tijekom dvije vegetacijske sezone na 4 lokacije ustanovili su da udio bjelančevina ne ovisi samo o genetskom potencijalu sorti već i o njihovoj sposobnosti da ostvare taj potencijal u različitim okolišnim uvjetima. Panozzo i Eagles (2000.) i Kaya i Akcura (2014.) navode kako genotipovi, okolina i interakcija genotip x okolina imaju značajne učinke na kvalitetu bjelančevina, premda okolina utječe više od genotipa. Williams i sur. (2008.) navode da na sadržaj bjelančevina najviše utječu okolina i interakcija genotip x okolina. Kelmendi i sur. (2009.) su utvrdili signifikantne razlike za prinos zrna i udio bjelančevina između genotipova, lokacije i godine te signifikantnu interakciju sorta $\mathrm{x}$ lokacija $\mathrm{x}$ godina.

\section{ZAKLJUČAK}

Na temelju provedenih istraživanja obavljenih u Osijeku o utjecaju genotipova i godine uzgoja na udio bjelančevina u zrnu možemo zaključiti sljedeće:

Utvrđene su statistički značajne razlike $(\mathrm{P}<0,01)$ utjecaja genotipa, godine $\mathrm{i}$ interakcije genotipa $x$ godine na udio bjelančevina u zrnu.

$\mathrm{S}$ obzirom na utjecaj godine, genotipa i njihove interakcije genotipovi uključeni u ovo istraživanje prema prosječnom udjelu bjelančevina u zrnu svrstali su se i II. (BC Anica, Basmati, BC Lorena, BC Ljepotica, BC Opsesija, Kraljica,Silvija, Sofru, Tenor, Tika Taka, Maja i Mia) i III. (BC Mandica) klasu.

Najveći udio bjelančevina od 13,8\% ostvaren je 2019. godine što prema Pravilniku o ugovornim odnosima pri otkupu pšenice prosječno svrstava genotipove u I klasu. U navedenoj godini imali smo $31,5(\mathrm{~mm})$ više oborina i 0,92 višu temperaturu zraka $\left({ }^{\circ} \mathrm{C}\right)$ od višegodišnjeg prosjeka.

Zbog različitog intenziteta utjecaja godine i genotipa na udio bjelančevina u zrnu, daljnja istraživanja u ovom smjeru su nužna kako bi se što bolje ispitao i utvrdio prosječni udio bjelančevina karakterističan za pojedini genotip kao i razlike između ispitivanih genotipova.

\section{INFLUENCE OF GENOTYPE AND YEAR ON THE WINTER WHEAT PROTEINS CONTENT AT THE OSIJEK LOCATION}

\section{SUMMARY}

During 2018, 2019 and 2020, field research was conducted on the influence of genotype, year and their interaction on protein content in winter wheat. Thirteen genotypes of winter wheat of domestic and foreign selection, which are represented on the domestic market, were included in the 


\section{G. Jukić i sur.: Utjecaj genotipa i godine na udio bjelančevina ozime pšenice na lokaciji Osijek}

experiment. The experiment was set up in HAPIH - Center for Seed and Seedlings at the location of Osijek (N $45^{\circ} 31^{\prime}$, E $\left.18^{\circ} 40^{\prime}\right)$ in two repetitions by Randomised Complete Block Design using with the standard agrotechniques for winter wheat. The aim of this study was to determine the influence of winter wheat genotype and year on protein content in order to group genotypes into classes according to the Policy on quality parameters and qualitative classes of wheat. Based on the results statistically high significant differences were found $(\mathrm{P}<0,01)$ among genotypes, years and genotype $\mathrm{x}$ year interactions for protein content. The average protein content of the three-year genotype study ranged from 11.5 to $13.4 \%$. The obtained results indicate the possibility of selecting genotypes with higher protein content.

Key words: winter wheat, genotype, protein, quality class

\section{LITERATURA}

1. Horvat, D., Drezner, G., Dvojković, K., Šimić, G., Španić, V., Magdić, D. (2012.): End-use quality of wheat cultivars in different environments. Sjemenarstvo, 29 (1-2), 5-11.

2. Jolánkai, M., Birkás, M. (2013.): Precipitation impacts on yield quantity and quality of wheat crop. In: Marić, S., Lončarić, Z., Proceedingsof 48th Croatian \& 8th International Symposium on Agriculture. Dubrovnik, Croatia, 17 - 22 February, 2013. FacultyofAgriculturein Osijek, Josip Juraj Strossmayer University of Osijek. 489-493.

3. Jukić, G., Varnica, I., Šunjić, K., Delić, I., Cegur, Ž. (2018.): Grupiranje najzastupljenijih sorti ozime pšenice u klase prema parametrima kvalitete, Proceedings/Abstracts, 11. International, scientific / professional conference, Agriculture in Nature and Environment Protection,Vukovar 88-89.

4. Kaya, Y., Akcura, M. (2014.): Effects of genotype and environment on grain yield and quality traits in breadwheat, Food Science and Technology, vol. 32, no. 2.

5. Kovačević, V., Rastija, M. (2014.): Žitarice, Sveučilište Josipa Jurja Strossmayera u Osijeku, Poljoprivredni fakultet u Osijeku, Osijek.

6. Kelmendi, B., Musa F., Berisha, D., Bekqeli, R., Cacaj, I., Fetahu, S., Rusinovci, I., Aliu, S., i Arifaj, A. (2009.): Ispitivanje nekih komponenti prinosa i kvalitete zrna hrvatskih sorti ozime pšenice u agroekološkim uvjetima Kosova, Zbornik radova 44. hrvatskog i 4. međunarodnog simpozija agronoma / Sonja Marić, Zdenko Lončarić (sur.). Osijek: Poljoprivredni fakultet u Osijeku, str. 325-329.

7. Panozzo, J. F., Eagles, H. A. (2000.): Cultivar and environmental effects on quality characters in wheat. Australian Journal of Agricultural Research, 51, 629-636.

8. Vollmera, E., Mußhoff, O. (2018.): Average protein content and its variability in winter wheat: a forecast model based on weatherparameters. Earthintercations, 22 (19): 1-24.

9. Williams, R. M., O’Brien, L., Eagles H. A., Solah, V. A., Jayasena, V. (2008): he influences of genotype, environment, and genotype $\mathrm{x}$ environment interaction on wheat quality. Australian Journal of Agricultural Research, 59, 95-111.

10. FAOSTAT (2018): http://www.fao.org/faostat/en/\#data/QC

11. Pravilnik o ugovorenim odnosima pri otkupu pšenice (NN 62/19).

12. Pravilnika o parametrima kvalitete i kvalitativnim klasama pšenice u otkupu pšenice roda 2018 . godine (NN 46/18). 


\section{G. Jukić i sur.: Utjecaj genotipa i godine na udio bjelančevina}

ozime pšenice na lokaciji Osijek

Adresa autora - authorsaddresses:

dr. sc. Goran Jukić, e-mail: goran.jukic@hapih.hr

Krešimir Šunjić, mag. spec.

Ivan Varnica, dipl. ing.

Doc. dr. sc. Ivana Rukavina

HAPIH - Centar za sjemenarstvo i rasadničarstvo

Usorska 19, 31000 Brijest

Ivica Delić, dipl. ing.

Ministarstvo poljoprivrede

Vukovarska 78, 10000 Zagreb
Primljeno - Received:

19.11.2020. 
